\title{
An Empirical Study of Motion Expressions in Mandarin Chinese
}

\author{
Ziyan $\mathrm{Xu}^{1}$ \\ ${ }^{1}$ School of Foreign Languages, Beijing Institute of Technology, Beijing, China \\ Correspondence: Xu Ziyan, School of Foreign Languages, Beijing Institute of Technology, No. 5 South \\ Zhongguancun Street, Haidian District, Beijing 100081, China. Tel: 86-156-5254-0107. E-mail: \\ xuziyan@sina.com
}

Received: September 6, 2013 Accepted: September 19, 2013 Online Published: November 24, 2013

doi:10.5539/ells.v3n4p53 URL: http://dx.doi.org/10.5539/ells.v3n4p53

\begin{abstract}
There are different views concerning the typology of Chinese. Based on the study of Motion events, Talmy (1985, 1991, 2000) categorises Chinese as a satellite-framed language, but Slobin (2004, p. 228) proposes Chinese belongs to what is called "equipollently-framed languages". Following an empirical study of Motion expressions in Mandarin Chinese, more evidence is found that Chinese speakers rely strongly on serial verb constructions. The Manner verbs in Chinese stories are not as varied as those in English stories while Path verbs are more varied in Chinese than in English. The result suggests that Chinese follows what Slobin (2004) categorises an equipollently-framed language.
\end{abstract}

Keywords: serial verb construction, equipollently-framed language, Manner verb, Path verb

\section{Theoretical Background}

\subsection{Talmy's $(1985,1991,2000)$ Linguistic Typology}

Talmy $(1985,2000)$ proposes a two-way typology differentiating satellite-framed languages from verb-framed languages on the basis of the characteristic pattern of encoding the information about the Path of movement. "Languages that characteristically map the core schema into the verb will be said to have a framing verb and to be verb-framed languages"; and "languages that characteristically map the core schema onto the satellite will be said to have a framing satellite and to be satellite-framed languages" (Talmy, 2000, p. 222). English, Russian, German, etc. are examples of satellite-framed languages and examples of verb-framed languages include Italy, French, Spanish, etc. Chinese is categorised as a satellite-framed language taking the second element in Chinese serial verb constructions similar to English satellite. Talmy explains that Path verbs often lose some features of independent verbs; as a result, they often do not function as full verbs. In addition, there is a small closed set of Path verbs.

\subsection{Slobin's (2004, 2006) Revised Language Typology}

There is still no agreement, however, regarding Talmy's (2000) dichotomy of verb-framed languages and satellite-framed languages (but see Hendriks et al., 2008; Beavers, Levin, and Tham, 2009). There are some problems with this classification (Peyraube, 2006). Firstly, the Chinese satellites listed by Talmy (2000) are optional. The main verb can express the meaning very well without them. For example, 掉diao4 "off", which Talmy (2000, p. 109), considers to be a satellite follows a Manner verb and takes the second position in serial verb constructions. For example in (1a), 掉diao4 follows the Manner verb 跑pao3 “run". While it is natural and grammatical to say (1b) without the satellite 掉diao 4 and the sentence meaning is not changed.

（1） a. 他跑掉了.

$\begin{array}{llll}\text { Tal } & \text { pao3 } & \text { diao4 } & \text { le0. } \\ \mathrm{He} & \text { ran } & \text { off } & \text { PFV }\end{array}$

"He has run off."

b. 他跑了.

$$
\begin{array}{lll}
\text { Tal } & \text { pao3 } & \text { le0. } \\
\text { he } & \text { ran } & \text { PFV }
\end{array}
$$

"He has run off." 
Secondly, Chinese satellites can stand alone as independent verbs, which is not possible with English satellites. Gao (2001, p. 62) points out that "these satellites in Chinese can also function as independent verbs themselves." In (2a), for example, the word 来lai2 "come" is used in the Manner + Path combination, with 跑pao3 "run" being the Manner verb and 来lai2 "come" being the Path verb. In this case, a serial verb construction is formed, which is called 连动式 “lian2 dong4 shi4" (Gao, 2001, p. 62) in Chinese grammar. In (2b), 来lai2 "come" is used independently as the main Path verb. And it is the same case with many other "satellites", e.g., 去qu4 "go", 回/hui2 “return”, etc.

(1) a. 从东边跑来一只鹅.

$\begin{array}{llllll}\text { Cong2 } & \text { dong1bian1 } & \text { pao3 } & \text { lai2 } & \text { yitzhil } & \text { e2 } \\ \text { from } & \text { east } & \text { run } & \text { come } & \text { one-CL } & \text { goose }\end{array}$

“A goose runs from the east."

b. 从东边来一只鹅.

Cong2 donglbian1 lai2 yi4zhil e2.

from east come one-CL goose

"A goose comes from the east."

Slobin treats serial verb constructions in Chinese as a different case, where two or more verbs, with or without arguments, co-occur in the same clause and express the same event. Because Path verbs can occur alone in Chinese, they cannot be regarded as satellites. Satellites are verb particles and affixes that do not occur alone. Slobin observes that in Chinese and other serial verb languages both Path and Manner receive equal weight. He proposes that it may be appropriate to have a third typological category to include serial verb languages like Thai and Chinese, which cannot be allocated to satellite-framed or verb-framed. Slobin (2004, p. 228) proposes the third type, which is called "equipollently-framed languages." In these languages, "both Manner and Path are expressed by 'equipollent' elements," which refer to those elements "that are equal in formal linguistic terms, and appear to be equal in force or significance" (Slobin, 2004, p. 228). Slobin (2006, p. 64) further explains equipollently-framed as "a kind of framing in which both Path and Manner have roughly equal morphosyntactic status." So he revises the definitions of verb-framed and satellite-framed by adding a third type- to have a trichotomy rather than Talmy's $(1985,2000)$ dichotomy typology. The following trichotomy has therefore been proposed (Slobin, 2004, p. 249). Equipollently-framed languages (Slobin, 2006, pp. 64-65) include:

(i) Serial-verb languages include Niger-Congo, Hmong-Mien, Sino-Tibetan, Tai-Kadai, Honkhmer and some Austronesian. In serial verbs languages, it is difficult to tell which verb is the main verb. The typical construction type is Manner verb + Path verb.

(ii) Bipartite-verb languages include Algonquian, Althabaskan, Hokan and Klamath-Takelman. Bipartite verbs consist of two morphemes, one expressing Manner, and the other expressing the Path. The typical construction type is [Manner + Path] verb.

(iii) Generic verb languages include Jaminjungan languages. There are only a small group of function verbs in these languages. The typical construction type is Manner coverb + Path coverb + generic verb.

Slobin points out two caveats concerning this revised typology. One is to place "languages on a cline of Manner salience (Note 1), rather than placing them into dichotomized or trichotomized typologies" (Slobin, 2004, p. 228). Manner salience is "the level of attention paid to Manner in describing events." Another is that "typological characterizations often reflect tendencies rather than absolute differences between languages" (Berman \& Slobin, 1994, p. 118). Naigles et al. (1998) investigate the verb use in adult English and Spanish in the descriptions of static and dynamic Motion events. On the one hand, they find that English speakers and Spanish speakers differ from each other in the degree of mentioning Manner of Motion and in the use of the preferred sentence frames, but not in the number of verb types. On the other hand, they find that Spanish speakers prefer Manner verbs to describe vertical Motions, which is contrary to the general assumption that Spanish speakers favour the use of Path verbs (Naigles et al., 1998, p. 543). They emphasise the importance of contexts on the manifestation of typological differences and call for "relevant parameters of language differences" (Naigles et al., 1998, p. 548). And interestingly, some researchers (Huang \& Tanangkingsing, 2005) propose a four-way typology based on Talmy's two-way typology. The vertical axis represents Path salience and the horizontal axis represents Manner salience. Chinese is considered having the highest Manner salience compared with six western Austronesian languages: Saisiyat, Malay, Tagalog, Tsou, Cebuano and Squliq. Ji (2009) approves of Slobin's proposal that Chinese is an equipollently-framed language in that it has the representative characteristics of both satellite-framed languages and verb-framed languages. 


\subsection{Serial Verb Construction in Chinese}

Chen and Guo (2008, pp. 7-8) point out that "the serial verb construction normally allows a maximum of three verbal components side by side in the order of Manner + Path + Deictic. Any of these three verb types can also form two-component constructions, or occur alone..." They list eight verb construction types: $\mathrm{M}+\mathrm{P}+\mathrm{D}, \mathrm{M}+\mathrm{P}$, $\mathrm{M}+\mathrm{D}, \mathrm{P}+\mathrm{D}, \mathrm{P}+\mathrm{P}, \mathrm{M}, \mathrm{P}$, and $\mathrm{D}$. In addition to the eight types of verb constructions, another serial verb construction, $\mathrm{P}+\mathrm{P}+\mathrm{D}$ and $\mathrm{P}+\mathrm{P}+\mathrm{P}$ should be added to Chen and Guo's (2008) groupings (see examples $3 \mathrm{i}$ and 3j) (Note 2). For the purpose of the present study, the verb constructions are broadly categorised into three types: (a) those with single verbs including M, P, and D, (b) serial verb constructions with a Manner verb, which include such types as $\mathrm{M}+\mathrm{P}+\mathrm{D}, \mathrm{M}+\mathrm{P}, \mathrm{M}+\mathrm{D}$, and (c) those without a Manner verb, which include $\mathrm{P}+\mathrm{D}, \mathrm{P}+\mathrm{P}$, $\mathrm{P}+\mathrm{P}+\mathrm{D}$, and $\mathrm{P}+\mathrm{P}+\mathrm{P}$ constructions. Examples of (3a), (3b), and (3c) employ single verbs to express Motion events. Examples from (3d) to (3j) employ serial verb constructions for the encoding of Motion events (examples are from the present study).

(3) a. M

但是到了晚上, 那个青蛙竟然偷偷地从瓶子里跑了. (IC 125)

$\begin{array}{llllllll}\text { Dan4shi4 } & \text { dao4 } & \text { le0 } & \text { wan3shang4, } & \text { na4 } & \text { ge4 } & \text { qinglwal jing4ran2 } \\ \text { but } & \text { arrive } & \text { PFV } & \text { evening } & \text { that } & \text { CL } & \text { frog } & \text { actually } \\ \text { toultou1 } & \text { de0 } & \text { cong2 } & \text { ping2zi0 } & \text { li3 } & \text { pao3 } & \text { le0. } & \\ \text { stealthily } & \text { AdvM } & \text { from } & \text { bottle } & \text { in } & \text { run } & \text { PFV } & \end{array}$

"But when evening came, the frog ran out of the bottle stealthily."

b. $\mathrm{P}$

这个小男孩跟着他的家人到了这个餐馆.

Zhe4 ge4 xiao3 nan2hai2 gen1 zhe0 talde0

this CL small boy follow DUR his

jialren2 dao4 le0 zhe4 ge4 canlguan3.

family members arrive PFV this CL restaurant

"This small boy arrived at this restaurant with his family members."

c. D

后来警察来了, 把劫匪带走了. (IC 109)

Hou4lai2 jing3cha2 lai2 le0, ba3 jie2fei3 dai3zou3 le0.

then policeman come PFV BA robber take away PFV

"Then the policeman came and took the robber away."

Sentences (3d), (3e) and (3f) list those serial verb constructions with a Manner verb.

d. $\mathrm{M}+\mathrm{P}+\mathrm{D}$

父亲忽然间把他的手杖往河里边扔过去, 然后那条小狗就迅速地跑过去把那手杖叮回来. (IC 117)

$\begin{array}{llllll}\text { Fu4qin1 } & \text { hulran2jian1 } & \text { ba3 } & \text { talde0 } & \text { shou3zhang4 } & \text { wang3 } \\ \text { father } & \text { suddenly } & \text { BA } & \text { his } & \text { cane } & \text { to } \\ \text { he2 } & \text { li3bian1 } & \text { reng1 } & \text { guo4 } & \text { qu4, } & \text { ran2hou2 } \\ \text { river } & \text { in } & \text { throw } & \text { pass } & \text { go } & \text { then } \\ \text { na4 } & \text { tiao2 } & \text { xiao3 } & \text { gou3 } & \text { jiu4 } & \text { xun4su4 } \\ \text { that } & \text { CL } & \text { small } & \text { dog } & \text { then } & \text { quickly } \\ \text { de0 } & \text { pao3 } & \text { guo4 } & \text { qu4 } & \text { ba3 } & \text { na4 } \\ \text { AdvM } & \text { ran } & \text { pass } & \text { go } & \text { BA } & \text { that } \\ \text { shou3zhang4 } & \text { diao1 } & \text { hui2 } & \text { lai2. } & \\ \text { cane } & \text { hold in mouth } & \text { return } & \text { come } & \end{array}$

"Suddenly, father threw the cane into the river and then the small dog ran to it quickly and held it back 
with its mouth."

e. $\mathrm{M}+\mathrm{P}$

这个时候, 一个人闯进了银行. (HC 214)

$\begin{array}{lllllllll}\text { Zhe4ge4 } & \text { shi2hou4, } & \text { yil } & \text { ge4 } & \text { ren2 } & \text { chuang3 } & \text { jin4 } & \text { le0 } & \text { yin2hang2. } \\ \text { this } & \text { time } & \text { one } & \text { CL } & \text { person } & \text { rush } & \text { enter } & \text { PFV } & \text { bank }\end{array}$

"At this time, a person rushed into the bank."

f. $M+D$

就看那个他们的那条爱犬飞快地向海中心游去. (IC 119)

Jiu4 kan4 na4 ge4 talmeno de0 na4 tiao2

then see that their GEN that CL

ai4 quan3 feilkuai4 de0 xiang4 hai3 zhong1xin1

beloved dog quickly AdvM towards sea centre

you 2 qu4.

swim go

"Then it can be seen that their beloved dog swam to the centre of the sea quickly."

Sentences from (3g) to (3j) are examples of serial verb constructions without a Manner verb.

g. $\mathrm{P}+\mathrm{D}$

结果就出来了一只猫头鹰. (IC 117)

$\begin{array}{llllllll}\text { Jielguo3 } & \text { jiu4 } & \text { chu1 } & \text { lai2 } & \text { le0 } & \text { yil } & \text { zhil } & \text { maoltou2ying2. } \\ \text { result } & \text { then } & \text { exit } & \text { come } & \text { PFV } & \text { one } & \text { CL } & \text { owl }\end{array}$

"As a result, an owl came out."

h. $\mathrm{P}+\mathrm{P}$

好不容易小宝回到了自己的房间. (IC 101)

Hao3 bu1 rong2yi4 xiao3 bao3 hui2 dao4 le0 zi4ji3 de3 fang2jian1.

fairly not easy small child return arrive PFV own GEN room

"The child finally went back to his room."

i. $\quad \mathrm{P}+\mathrm{P}+\mathrm{D}$

当蜂巢掉下来的时候, 小黄还没有意识到它已经处于危险之中. (IC 126)

$\begin{array}{llllllll}\text { Dang1 } & \text { fenglchao2 } & \text { diao4 } & \text { xia4 } & \text { lai2 } & \text { de0 } & \text { shi2hou4, Xiao3 Huang2 } \\ \text { when } & \text { bee hive } & \text { fall } & \text { descend } & \text { come } & \text { NOM time } & \text { Xiao Huang } \\ \text { hai2 } & \text { mei2you3 } & \text { yitshi2dao4 } & \text { tal } & \text { yi3jingl } & \text { chu3yu2 } & \text { weilxian3 zhilzhong1. } \\ \text { yet } & \text { not } & \text { realise } & \text { it } & \text { already } & \text { exist } & \text { danger } & \text { in }\end{array}$

"When the bee hive fell down, Xiao Huang did not realise that it was already in danger."

j. $\quad \mathrm{P}+\mathrm{P}+\mathrm{P}$

一家人欢快地进入到了饭馆里. (IC 108)

$\begin{array}{lllllllll}\text { Yiljial ren2 } & \text { huan1kuai3 } & \text { de0 } & \text { jin4 } & \text { ru4 } & \text { dao4 } & \text { le0 } & \text { fan4guan3 } & \text { li3. } \\ \text { family members } & \text { happily } & \text { AdvM } & \text { enter } & \text { enter } & \text { arrive } & \text { PFV } & \text { restaurant } & \text { in } \\ \text { "The family entered the restaurant happily." } & & & & & & \end{array}$

As can be illustrated in the previous examples, there are normally three verbal components in a serial verb construction, while there are cases that more than three Motion verbs are used together without any interruptions. For example in ( $3 \mathrm{k})$, the serial verb construction consists of $\mathrm{M}+\mathrm{P}+\mathrm{D}+\mathrm{P}+\mathrm{P}$. In such cases, the construction can be treated as a combination of two serial verb constructions of $\mathrm{M}+\mathrm{P}+\mathrm{D}$ and $\mathrm{P}+\mathrm{P}$. 
k. 于是它就静悄悄地从瓶子里爬出来溜走了. (HC 228)

$\begin{array}{llllllll}\text { Yu2shi4 } & \text { tal } & \text { jiu4 } & \text { jing4qiaoqiaol } & \text { de0 } & \text { cong2 } & \text { ping2zi0 } & \text { li3 } \\ \text { so } & \text { it } & \text { then } & \text { quietly } & \text { AdvM } & \text { from } & \text { bottle } & \text { in } \\ \text { pa2 } & \text { chu1 } & \text { lai2 } & \text { liul } & \text { zou3 } & \text { le0. } & & \\ \text { climb } & \text { exit } & \text { come } & \text { sneak off } & \text { leave } & \text { PFV } & & \end{array}$

"So it stealthily climbed out of the bottle and sneaked off."

Another point to notice is that some verbs in Chinese are polysemic; therefore it is necessary to distinguish whether they are Manner verbs, Path verbs, Cause of Motion verbs, non Motion verbs or even other parts of speech rather than verbs on the basis of the contexts in which the words are used. For example, 闯 chaung3 "rush" in (4a) is a Motion verb and in (4b) is not.

(4) a. 他突然被一个闯进银行的人绊倒了. (IC 115)

$\begin{array}{llllllllllll}\text { Ta1 tulran2 } & \text { bei4 } & \text { yil } & \text { ge4 } & \text { chuang3 } & \text { jin4 } & \text { yin2hang2 } & \text { de0 } & \text { ren2 } & \text { ban4dao3 } & \text { le0. } \\ \text { he suddenly } & \text { BEI } & \text { one } & \text { CL } & \text { rush } & \text { enter bank } & \text { NOM } & \text { person } & \text { stumble } & \text { PFV }\end{array}$

"He was stumbled over by a man rushing into the bank."

b. 小青蛙一看闯了祸, 就赶快逃跑呀. (IC 106)

$\begin{array}{lllllll}\text { Xiao3 } & \text { qing1wal } & \text { yil } & \text { kan4 } & \text { chuang3 } & \text { le0 } & \text { huo4, } \\ \text { small } & \text { frog } & \text { once } & \text { see } & \text { cause } & \text { PFV } & \text { trouble } \\ \text { jiu4 } & \text { gan3kuai4 } & \text { tao2pao3 } & \text { ya0. } & & & \\ \text { then } & \text { hurry } & \text { escape } & \text { interj } & & & \end{array}$

"Seeing that it had caused some trouble, the small frog escaped in a hurry."

The word 飞 feil is a Manner verb in (5a) with the meaning of "fly" and it is an adverb with the meaning of "fast" in $(5 b)$.

(5) a. 因此蜜蜂全都飞了出来. (HC 218)

$\begin{array}{lllllll}\text { Yin1ci3 } & \text { mi4feng1 } & \text { quan2doul } & \text { feil } & \text { le0 } & \text { chul lai2. } \\ \text { so } & \text { bee } & \text { all } & \text { fly } & \text { PFV } & \text { exit come }\end{array}$

"So all the bees fly out."

b. 这时候小狗就飞快地跑过去. (IC 130)

$\begin{array}{lllllllllll}\text { Zhe4 } & \text { shi2hou4 } & \text { xiao3 } & \text { gou3 } & \text { jiu4 } & \text { feil } & \text { kuai4 } & \text { de0 } & \text { pao3 } & \text { guo4 } & \text { qu4. } \\ \text { this } & \text { time } & \text { small } & \text { dog } & \text { then } & \text { fast } & \text { quickly } & \text { AdvM } & \text { run pass } & \text { go }\end{array}$

"At this time, the small dog ran to it quickly."

走 zou 3 means "walk" in (6a) and it means "leave" in (6b), so it is a Manner verb in the former sentence and it is a Path verb in the latter.

(6) a. 小比特走到自己的房间. (IC 107)

\begin{tabular}{|c|c|c|c|c|}
\hline Xiao3 & Bi3Te4 & zou 3 & dao4 & $z i 4 j i 3$ \\
\hline small & Peter & walk & arrive & GEN \\
\hline
\end{tabular}

"Small Peter walked to his own room."

b. 然后一家人就气呼呼地走了. (IC 104)

$\begin{array}{llllll}\begin{array}{l}\text { Ran2hou4 } \\ \text { then }\end{array} & \text { yiljialren2 } & \text { jiu4 } & \text { qi4hulhul de } & \text { zou3 } & \text { le0. } \\ \text { whole family members } & \text { then } & \text { angrily } & \text { leave } & \text { PFV }\end{array}$

"Then the whole family left angrily."

Similarly, 翻 fan1 is a Manner verb in (7a). It functions as a Path verb in (7b). The difference is that the first 翻 fanl in (7b) follows a neutral verb 打 $d a 3$ "strike" and the second 翻 fanl functions independently as a Path verb. 
(7) a. 他悄悄地翻过了那根枯木. (HC 225)

$\begin{array}{llllll}\text { Tal } & \text { qiaolqiaol } & \text { de0 } & \text { fan1 } & \text { guo4 } & \text { le0 } \\ \text { he } & \text { quietly } & \text { AdvM } & \text { climb over } & \text { cross } & \text { PFV } \\ \text { na4 } & \text { gen1 } & k u 1 & \text { mu4. } & & \\ \text { that } & \text { CL } & \text { rotten } & \text { wood } & & \end{array}$

"He climbed over that rotten wood quietly."

b. 座位和桌子都被打翻了, 酒杯也翻了. (IC 112)

$\begin{array}{llllllll}\begin{array}{l}\text { Zuo4wei4 } \\ \text { chair }\end{array} \text { he } & \text { and } & \text { table } & \text { all } & \text { BEI } & \text { strike } & \text { fanl } & \text { le0, } \\ \text { jiu3 beil } & \text { ye3 } & \text { fanl } & \text { le0. } & & & \text { PFV } \\ \text { wine cup } & \text { also } & \text { topple } & \text { PFV } & & \\ \text { "Both tables and chairs toppled over and the wine cups toppled over as well." }\end{array}$

From the current literature, we can find that there is no agreement concerning the linguistic typology of Chinese. The serial verb construction in Chinese does attracts attention in the categorization.

\section{The Present Study}

\subsection{Hypothesis}

According to Slobin $(2004,2006)$, Chinese is an equipollently-framed language, which means that Manner and Path are expressed by equipollent elements in Chinese. In other words, Manner verbs and Path verbs are equal in formal linguistic terms and appear to be equal in force or significance (Slobin, 2004, p. 228). This proposal elaborates on Talmy's (2000) dichotomized typology, according to which Chinese is a satellite-framed language, in which Path verbs lose some features of independent verbs so that they often do not function as full verbs, and there is a small closed set of Path verbs. Slobin assumes that languages cannot easily be divided into dichotomized or trichotomized typologies: instead they should be placed "on a cline of Manner salience (Note 3). If Manner is salient in one language, such as English, language users will pay more attention to it and consequently the number of Manner verbs will increase in the process of language development.

In Chinese, Path verbs can stand alone as independent verbs and they have the same force and status as Manner verbs. It is hypothesized that Chinese speakers will strongly rely on serial verb constructions, in which Manner and Path are expressed by equivalent grammatical forms. However, in Chinese Manner is not as salient as in English; therefore it is also hypothesized that there will be less variation in Manner verb types in Chinese than in English. On the other hand, if Chinese is an equipollently-framed language, in which Manner and Path are both expressed with verbs which have a full lexical meaning, we can expect informants to make use of a great variety of Path verbs in the Chinese. In English by contrast, Path is more frequently expressed with satellites so that there is only a small closed set of Path verbs in this language. Consequently, Path verbs are more varied in Chinese than in English. The hypothesis can be summarised as follows:

Chinese speakers will rely strongly on serial verb constructions. The Manner verbs in Chinese stories will not be as varied as those in English stories while Path verbs are more varied in Chinese than in English.

\subsection{Subjects}

The subjects include 30 grade one (IC group) and 30 grade four (HC group) university students from Beijing Institute of Technology (BIT), who come from all over China, but all speak Mandarin as the first language.

\subsection{Materials}

The materials used include two father-and-son comics (Plauen 1976), which will be called the Bank story (story one) and the Dog story (story two). There are two additional frog stories (Mayer, 1969): Frog, where are you? (story three) and Frog goes to dinner (story four).

Frog, where are you? has been analysed in many Motion event research in many languages including English and Chinese (e.g., Berman \& Slobin, 1994; Slobin, 1996, 1997, 2000;Chen, 2005). This material is adopted for the comparison with previous research. Frog goes to dinner (Mayer, 1969) is a book which depicts a lot of movements of the frog in the restaurant so that it provides an excellent material for the description of Motion events for every subject. Father-and-son comic strip about a Bank story (Plauen, 1976) has been used for the investigation of language proficiency and Motion events descriptions by several researchers, e.g., Daller, Van 
Hout and Treffers-Daller (2003); Treffers-Daller, Özsoy and Van Hout (2007).

\subsection{Tasks}

Each subject was presented with a task explanation written in English to ensure every student obtained exactly the same instructions. The subjects were informed that they were going to tell stories based on materials from Mayer (1969) and Plauen (1976), and that these would be tape-recorded. The subjects were expected to tell the stories in as much detail as possible.

We gave an anonymous number to each subject and decided to split groups in half. The first half of the participants of both HC group and IC group, that is HC201-HC215 and IC301-IC315, told the story Frog goes to dinner and Bank story. The other half, that is HC216-HC230 and IC316-IC330 toll the story Frog, where are you? and Dog story.

\subsection{Transcriptions and Coding}

The stories were first tape-recorded and then transcribed by the investigator. Then the data were transformed into CHAT format, the transcription and coding format developed by MacWhinney (2000). The results were subsequently analysed with the help of statistical tools.

\section{Results}

Slobin (1997) proposes that regarding Motion event descriptions, satellite-framed languages possess a larger and more diverse lexicon of Manner verbs compared with verb-framed languages. And Manner verbs in satellite-framed languages are more fine-grained than those in verb-framed languages. The hypothesis consists of two parts: (a) Manner in Chinese does not receive the same salience as in English, and (b), Chinese speakers will strongly rely on serial verb constructions. To test this hypothesis, firstly, the types and tokens of both Manner verbs and Path verbs in all four Chinese stories are presented to illustrate the frequency and diversity of the Motion verbs in Chinese. Secondly, since Chinese speakers can express Motion both in the use of bare verbs and the use of serial verb constructions, a comparison between bare verbs and serial verb constructions is made to reveal to what degree Chinese speakers rely on serial verb constructions. This is interesting from a typological perspective because Chinese and English differ very much at this point. Thirdly, a further distinction is made among the different serial verb constructions on the basis of whether they contain Manner verbs or not.

\subsection{Use of Manner Verbs}

Eleven Manner verbs in the Bank story are used by Chinese native speakers (CC1). The frequency of the verb use reveals that the Manner verb 冲 chongl "dash" is employed with the highest frequency, and is twice as frequent as the Manner of Motion verb 跑 pao3 “run". The word 冲 chong1 "dash" indicates the rapid action of the movement, therefore it can reflect the movement of the robber into the bank more vividly as is depicted in picture 1 of the comic. Other words employed to describe the same scene include 闯 chuang3 "rush", 奔ben1 "gallop", and 走zou3 “walk".

There are twelve types of Manner verbs in Chinese native speakers Dog story in Chinese (CC2). Speakers use 走 zou3 "walk" and 跑 pao3 "run" with similar frequency in this story. But these two words describe different scenes. When 走 zou 3 "walk" functions as a Manner verb in this story, it overwhelming describes the scene that the gentleman/father and son come to the bank of the river. 跑 pao3 "run" describes the Motion of the dog into the river, while some speakers employ Manner verbs such as 游(泳) you2(yong3) “swim”, 跳 tiao4 “jump", and 冲 chongl "dash" to describe this scene.

There are 21 types of Manner verbs in story three Frog goes to dinner (CC3). The emphasis of the description is on the Motion of the frog; therefore subjects use a variety of Manner verbs in the description of the scene, which include 跳tiao4 “jump”, 钻zuan1 “make one's way into”, 跑pao3 “run”, 躲duo3 “hide”, 跃yue4 “jump”, 蹦 beng4 "jump", 冒 mao4 "pop up", 藏 cang2 "hide”, 飞feil "fly", 爬pa2 "climb/crawl”, 扑 pu1 "throw oneself

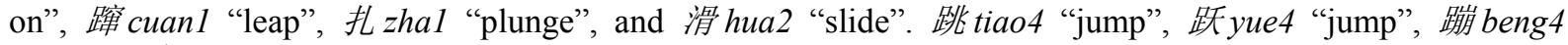
"jump", 蹿 cuanl "leap" have similar meanings in Chinese. According to the Contemporary Chinese Dictionary (Chinese-English Edition) (2002), 跳 tiao4 means "jump, leap, bounce, skip"; 跃 yue4 means "jump, leap, bounce, spring”; 蹦 beng4 “leap, jump, spring”, 蹿 cuan 1 means “leap up, leap forward”, but the word 跳 tiao4 "jump" is used with a much higher frequency than other words. 走 zou 3 is used as a Path verb rather than a Manner verb when it describes the Motion of the frog in this story because it follows other Manner verbs such as 跳 tiao4 "jump" and 飞feil "fly" as in (8a) and (8b). 
(8) a. 小青蛙又飞走了. (HC 206)

$\begin{array}{llllll}\text { Xiao3 } & \text { qinglwal } & \text { you4 } & \text { feil } & \text { zou3 } & \text { le0. } \\ \text { small } & \text { frog } & \text { again } & \text { fly } & \text { leave } & \text { PFV }\end{array}$

"The small frog flew away again."

b. 青蛙又高高兴兴地跳走了. (HC 209)

$\begin{array}{lllllll}\text { Qinglwal } & \text { you4 } & \text { gaolgaolxing4xing4 } & \text { de0 } & \text { tiao4 } & \text { zou3 } & \text { le0. } \\ \text { frog } & \text { again } & \text { happily } & \text { AdvM } & \text { jump } & \text { away } & \text { PFV }\end{array}$

"The frog jumped away happily again."

There are 27 types of Manner verbs used in Frog, where are you? (CC4). The word 爬pa2 is used with the highest frequency in this story. It should be noted that this word has two translation equivalents in English, namely climb and crawl. Therefore it can denote both the Motion of moving upwards/downwards and forwards/backwards. For example, 爬pa2 equals to "crawl" in (9a) and it means "climb" in (9b). It can be widely used to describe the Motion of the boy, the dog, the frog, and the mole. 跑 pao3 "run" appears with a relatively high frequency in this story as well because it can describe the Motion of a number of different protagonists - the boy, the dog, and the deer.

（9） a. 但是却有一只地鼠从洞里爬了出来. (HC 218)

$\begin{array}{lllllllllllll}\text { Dan4shi4 } & \text { que4 } & \text { you3 } & \text { yil } & \text { zhil } & \text { di4shu3 } & \text { cong2 } & \text { dong4 } & \text { li3 } & \text { pa2 } & \text { le0 } & \text { chu1 lai2. } \\ \text { but } & \text { but } & \text { exit } & \text { one } & \text { CL } & \text { mole } & \text { from } & \text { hole } & \text { in } & \text { crawl } & \text { PFV } & \text { exit } & \text { come }\end{array}$

"But a mole crawled out of the hole."

b. 小狗也爬上了窗户. (HC 216)

$\begin{array}{lllllll}\text { Xiao3 } & \text { gou3 } & \text { ye3 } & \text { pa2 } & \text { shang4 } & \text { le0 } & \text { chuanglhu4. } \\ \text { small } & \operatorname{dog} & \text { also } & \text { climb } & \text { up } & \text { PFV } & \text { window }\end{array}$

"The small dog also climbed up the window."

There are 36 types of Manner verbs in total. These words appear with different frequencies, with 跳 tiao4 "jump" being used with the highest frequency followed by Manner verbs such as 跑 pao3 “run", 走 zou3 “walk", and 爬 pa2 “climb/crawl”. All these Manner words are very common in Chinese. Since frog is the main character in the two frog stories and 跳 tiao4 "jump" is the most common way to describe its Motion, this explains the reason for the highest frequency of this word. On the other side of the frequency rank, seven words are only used once in the four stories, which indicates that they are not the common way to describe the Motion events in the four stories.

Table 1 provides all the Manner verbs in the four Chinese stories from 30 Chinese EFL learners (CC1234). There are 36 types of Manner verbs in total. These words appear with different frequencies, with 跳 tiao 4 "jump" being used with the highest frequency followed by Manner verbs such as 跑 pao3 “run”, 走 zou3 “walk”, and 爬 pa2 “climb/crawl”. All these Manner words are very common in Chinese. Since frog is the main character in the two frog stories and 跳 tiao 4 "jump" is the most common way to describe its Motion, this explains the reason for the highest frequency of this word. On the other side of the frequency rank, seven words are only used once in the four stories, which indicates that they are not the common way to describe the Motion events in the four stories. 
Table 1. Manner verbs in the four stories of Chinese EFL learners (CC 1234) (36 types)

\begin{tabular}{|c|c|c|c|c|}
\hline Order & Character & Pinyin & Meaning & Frequency \\
\hline 1 & 跳 & tiao4 & "jump" & 199 \\
\hline 2 & 跑 & pao3 & "run" & 152 \\
\hline 3 & 走 & zou3 & "walk" & 109 \\
\hline 4 & 爬 & pa2 & "climb/crawl" & 104 \\
\hline 5 & 钻 & zuanl & "make ones way into" & 75 \\
\hline 6 & 冲 & chong1 & "dash" & 54 \\
\hline 7 & 躲 & duo3 & "hide" & 31 \\
\hline 8 & 飞 & feil & "fly" & 31 \\
\hline 9 & 奔 & benl & "gallop" & 23 \\
\hline 10 & 蹦 & beng4 & “jump” & 20 \\
\hline 11 & 跃 & yue4 & “jump” & 18 \\
\hline 12 & 冒 & mao4 & "pop up" & 14 \\
\hline 13 & 游(泳) & you 2 yong 2 & "swim" & 12 \\
\hline 14 & 绊 & ban4 & stumble & 10 \\
\hline 15 & 赶 & $\operatorname{gan} 3$ & "hurry through" & 9 \\
\hline 16 & 嗐 & cuanl & "leap" & 8 \\
\hline 17 & 藏 & cang2 & "hide" & 7 \\
\hline 18 & 扑 & pul & "throw oneself on" & 6 \\
\hline 19 & 撞 & zhuang4 & "bump" & 6 \\
\hline 20 & 闯 & chuang3 & "rush" & 6 \\
\hline 21 & 遛 & liu4 4 & $\begin{array}{l}\text { "stroll/walk an animal } \\
\text { or a bird" }\end{array}$ & 4 \\
\hline 22 & 扎 & zhal & "plunge" & 3 \\
\hline 23 & 滑 & hua2 & "slide" & 3 \\
\hline 24 & 浮 & $f u 2$ & "float" & 3 \\
\hline 25 & 溅 & jian4 & “splash" & 2 \\
\hline 26 & 流 & $\operatorname{liu} 2$ & "flow" & 2 \\
\hline 27 & 攀 & pan1 & “clamber" & 2 \\
\hline 28 & 踩 & cai3 & "trample" & 2 \\
\hline 29 & 漂 & piaol & "float" & 2 \\
\hline 30 & 翻 & fanl & "climb over" & 1 \\
\hline 31 & 踏 & ta4 & "tread" & 1 \\
\hline 32 & 涉 & she4 & "wade" & 1 \\
\hline 33 & 跨 & kua4 & "stride" & 1 \\
\hline 34 & 趟 & tangl & "wade" & 1 \\
\hline 35 & 乘 & cheng2 & "travel by vehicle" & 1 \\
\hline 36 & 迈 & mai4 & "stride" & 1 \\
\hline
\end{tabular}

\subsection{Use of Path Verbs}

The Path verbs used in the four Chinese stories can be categorised into three sub-groups according to the constructions they are used in the stories: (a) those only used in serial verb constructions but cannot stand alone 
as main verbs, (b) those which can stand alone as main verbs but are not used in serial verb constructions, and (c) those which can be used both in serial verb constructions and stand alone. There are 16 types of Path verbs in story one (CC1), 14 in story two (CC2), 25 in story three (CC3), and 27 in story four (CC4). Concerning the use of Path verbs in CC1, 下xia4 “descend", 翻 fanl “topple", 起 qi3 “rise”, 入 ru4 “enter", 转 zhuan4 “pass on", and 回 hui2 "return" only appear in serial verb constructions. 围wei2 "surround" stands alone as a main verb. 进 jin4 “enter", 出 chu1 “exit", 走 zou3 “leave", 上 shang4 "ascend", 摔 shuail “fall down", 倒 dao3 “fall down", 到 dao4 "arrive", 掉 diao4 "fall", and 过 guo4 "pass" function both in serial verb constructions and stand alone. Among the Path verbs in CC2, 回hui2 "return" is used with the highest frequency and it is most frequently used following such verbs as 叮 diaol "hold in mouth", 捡jian3 "pick up", 送 song4 “deliver", 衔 xian2 "hold in the mouth", 拿 na2 "hold". These verbs in Chinese are similar to verbs of conveyance in English (Berman and Slobin 1994), which constitute serial verb constructions with 回来 hui2lai2 "return come". 下xia4 "descend" can also function alone as the main verb in story two. 开kail "part/open" and 离li2 are frequently used together, that is 离开li2kai2, meaning "leave". There are some cases that 掉 diao4 "fall/go away" appears in the first slot of a serial verb construction. 跟 gen 1 "follow" and 随 sui2 "follow" are independent Path verbs. 起 qi3 “rise" appears in the same construction of 回 hui2 "return". 跑 pao3 usually functions as a Manner of Motion verb, meaning "run", but it is a Path verb in this story, meaning "leave the original place". For example, in (10), 跑 pao3 indicates that father and son leave their original place and come to the beach. It does not mean that they come here by "running".

(10) 父亲带着儿子还有他们的爱犬跑到沙滩上去遛狗. (IC 119)

$\begin{array}{lllllll}\text { Fu4qin1 } & \text { dai4zhe0 } & \text { er2zi0 } & \text { hai2you3 } & \text { talmen0de0 } & \text { ai4 } & \text { quan3 } \\ \text { father } & \text { lead DUR } & \text { son } & \text { also } & \text { their } & \text { beloved } & \text { dog } \\ \text { pao3 } & \text { dao4 } & \text { shaltan1 } & \text { shang2 } & \text { qu4 } & \text { liu4 } & \text { gou3. } \\ \text { leave } & \text { arrive } & \text { beach } & \text { on } & \text { go } & \text { stroll } & \text { dog }\end{array}$

"Father, son, and their beloved dog went to the beach to stroll the dog."

There are altogether 32 types of Path verbs in the four Chinese stories. They are categorised according to the construction types they are used in these stories. (11) are Path verbs that are used only in serial verb constructions; (12) are Path verbs that only stand alone as main verbs; and (13) are those that can be used in both constructions.

(11) (11 types)

溜liul “leave sneakily”, 离li2 leave/part”, 开kail “open/part” (Note 4), 入 ru4 “enter”, 散san4 “scatter”, 跑 pao3 “leave”, 芏 zhui4 “fall”, 绕 rao4 "go around”, 迁yul "bypass”, 转zhuan4 "pass on”, 起 qi3 "rise"

(12) (4 types)

退 tui4 “retrieve”, 围wei2 “surround”, 凑 cou4 “approach”, 跟 genl "follow”

(13) (17 types)

到dao4 “arrive", 出 chul “exit”, 回hui2 “return”, 进jin4 “enter”, 下xia4 “descend”, 过guo4 “pass", 掉 diao4 "fall", 走 zou3 "go away", 上 shang4 “ascend", 摔 shuail "fall down", 追/追逐 zhuil/zhuilzhu2 “pursue” (Note 5), 逃tao2 “escape”, 倒dao3 “fall down”, 落luo4 “fall”, 跌 die1 “fall”, 随sui2 “follow”, 翻 fanl "topple"

To summarise, the number of Manner and Path verb types are 36 and 32 respectively in the four Chinese stories of Chinese EFL learners. The ratio of Manner versus Path verb types within total number of Motion verb types is 1.125:1 (36/32).

\subsection{Serial Verb Constructions}

As Chen and Guo (2008) have demonstrated, Chinese speakers rely strongly on the use of serial verb constructions to express Motion events rather than one single Manner verb, Path verb, or deictic Motion verbs. To investigate this, one scene is chosen from each of the four stories (see the appendix) and coded according to different Motion verb types: (a) single Manner verbs, (b) serial verb constructions with Manner verbs, (c) single Path verbs, and (d) serial verb constructions with Path verbs. These scenes chosen are very important for the development of the corresponding stories and therefore are described by most subjects. These scenes include

(i). Picture 1 in story one - robber goes into the bank 
(ii). Picture 2 in story two- dog goes into the river

(iii). Picture 2 in story three- frog goes into the boy's pocket

(iv). Picture 2 in story four - frog goes out of bottle

In seven cases these four scenes are described by one single verb and in 85 cases by serial verb constructions. That is, the frequency of the use of serial verb constructions is as high as $92 \%$, as against $8 \%$ percent of single Motion verbs.

The previous four scenes all involve a boundary crossing. If we turn to non boundary-crossing events, we can get the same result. For example, for the description of the scene that the frog falls on the saxophonist's head, where the frog does not cross a boundary, except for four cases in which the informants avoid expressing the event, all the Chinese speakers choose serial verb constructions rather than single Motion verbs.

\section{Analysis and Discussion}

To summarise, there are 11, 12, 21, and 27 Manner verbs and 16, 14, 25, and 27 Path verbs respectively in the four Chinese stories. There are 36 types of Manner verbs and 32 types of Path verbs in total in the four Chinese stories. This indicates that the types of Manner verbs are only slightly more varied than those of Path verbs. This can be explained by the high frequency of serial verb constructions in the four representative scenes of the four stories to encode Motion events rather than single verbs, which is $92 \%$ against $8 \%$. The serial verb constructions include such types as $\mathrm{M}+\mathrm{P}+\mathrm{D}, \mathrm{M}+\mathrm{P}, \mathrm{M}+\mathrm{D}, \mathrm{P}+\mathrm{D}, \mathrm{P}+\mathrm{P}, \mathrm{P}+\mathrm{P}+\mathrm{D}$ and $\mathrm{P}+\mathrm{P}+\mathrm{P}$ constructions. This indicates that Path verbs in serial verb constructions often take the second slot when used with a Manner verb or take the first slot when used with deictic Motion verbs. The serial verb constructions with a Manner verb amount to as high as $96 \%$.

The study finds that the classification of Chinese as an equipollently-framed language as proposed by Slobin (2004, 2006, Hendriks et al. 2008) is more appropriate for the current study. It provides evidence that the lexicon of Manner verbs in Chinese is not as rich as English Manner verb lexicon, especially with respect to the second tier Manner verbs. Since Chinese possesses serial verb constructions, in which Manner verb and Path verb have equipollent status, there is a richer lexicon of Path verbs in Chinese than in English. According to Slobin (1996), if Manner (or Path) is always readily encodable in one language, speakers will pay more attention to it and in turn Manner (or Path) verbs will become even richer. Chinese, as an equipollently framed language, Manner and Path are equally expressed in serial verb constructions. Therefore, Chinese speakers will pay attention to both Manner and Path so that the range of Path verbs increases with time. The study supports Hypothesis that Chinese speakers rely strongly on serial verb constructions and that Chinese is on a lower rank in the cline of Manner salience than English.

\section{Conclusion}

The result provides evidence that Chinese speakers rely strongly on serial verb constructions, which is in accordance with previous research about Chinese (Chen \& Guo, 2008). The Manner verbs in Chinese stories are not as varied as those in English stories, especially the use of second tier Manner verbs, whereas Path verbs are more varied in Chinese than in English. Considering that Path verbs can occur alone in Chinese and that the Chinese satellites listed by Talmy (2000) are optional, they cannot be regarded as satellites. Therefore, the present study provides evidence for Slobin's (2004) revised typology of treating serial verb languages as an equipollently-framed language (see also Hendriks at al. 2008).

\section{Acknowledgements}

I appreciate Professor Jeanine Treffers-Daller's help in the writing of my Ph. D dissertation, on which the present article is based. I would like to express my gratitude to all the anonymous subjects from Beijing Institute of Technology. I would also extend my appreciation to the staff in BIT who helped me with the recruitment of the subjects. They are Lai Luning, Li Xiaozhong and Gong Jun.

\section{References}

Beavers, J., Levin, B., \& Tham, S. W. (2009). The typology of Motion expressions revisited. Journal of Linguistics. Retrieved from http://comp.ling.utexas.edu/ jbeavers/Motion-typology-working.pdf

Berman, R. A., \& Slobin, D. I. (1994). Relating events in narrative: A cross-linguistic developmental study. Hillsdale, NJ: L. Erlbaum.

Chen, L. (2005). The acquisition and use of Motion event expressions in Chinese. Retrieved from http://www.ucs.louisiana.edu/ 
Chen, L., \& Guo, J. S. (2008). Motion events in Chinese novels: Evidence for an equipollently-framed language. Journal of Pragmatics. http://dx.doi.org/10.1016/j.pragma.2008.10.015.

Daller, H., van Hout, R., \& Treffers-Daller, J. (2003). Lexical richness in spontaneous speech of bilinguals. Applied Linguistics, 24(2), 197-222. http://dx.doi.org/10.1093/applin/24.2.197

Gao, H. (2001). The physical foundation of the patterning of physical action verbs: A study of Chinese verbs. Lund, Sweden: Lund University Press.

Hendriks, H., Ji, Y., \& Hickmann, M. (2008). Typological issues regarding the expression of caused Motion: Chinese, English and French. In M. Brala (Ed.), Space and Time in Language and Literature. Cambridge, UK: Cambridge Scholars Press.

Hickmann, M., \& Robert, S. (Eds.). Space in languages: Linguistic systems and cognitive categories (pp. 59-81). Amsterdam/Philadelphia: John Benjamins.

Huang, S. F., \& Tanangkingsing, M. (2005). Reference to Motion Events in Six Western Austronesian Languages: Toward a Semantic Typology. Oceanic Linguistics, 44(2). http://dx.doi.org/10.1353/ol.2005.0035

Ji, Y. L. (2009). The expression of voluntary and caused Motion events in Chinese and in English: Typological and developmental perspective. Unpublished doctoral dissertation. Cambridge University.

Mayer, M. Frog Goes to Dinner. 1969.

Mayer, M. Frog, where are you? 1969.

Naigles, L. R., Eisenberg, A. R., Kako, E. T., Highter, M., \& McGraw, N. (1998). Speaking of Motion: Verb use in English and Spanish. Language and cognitive processes, 13(5), 521-549. http://dx.doi.org/10.1080/016909698386429

Peyraube, A. (2006). Motion events in Chinese: A diachronic study of directional complements. In

Plauen, E. O. (1976). Vater und Sohn, Band 2. Ravensburger Taschenbuch.

Slobin, D. I. (1996). Two ways to travel: Verbs of Motion in English and Spanish. In M. Shibatani, \& S. A. Thompson (Eds.), Grammatical constructions: Their form and meaning (pp. 195-217). Oxford: Oxford University Press.

Slobin, D. I. (1997). Mind, code, and text. In J. Bybee, J. Haiman, \& S. A. Thompson (Eds.), Essays on language function and language type: Dedicated to T. Givón (pp. 437-467). Amsterdam/Philadelphia: John Benjamins.

Slobin, D. I. (2000). Verbalized events: A dynamic approach to linguistic relativity and determinism. In S. Niemeier, \& R. Dirven (Eds.), Evidence for linguistic relativity (pp. 107-138). Amsterdam/Philadelphia: John Benjamins.

Slobin, D. I. (2002). Language and thought online: Cognitive consequences of linguistic relativity. In D. Gentner, \& S. Goldin-Meadow (Eds.), Language in mind: Advances in the investigation of language and thought (pp. 157-191). Cambridge, MA: MIT Press.

Slobin, D. I. (2004). The many ways to search for a frog: Linguistic typology and the expression of Motion events. In S. Strömqvist, \& L. Verhoeven (Eds.), Relating events in narrative: Typological and contextual perspectives (pp. 219-257). Mahwah, NJ: Lawrence Erlbaum Associates.

Slobin, D. I. (2006). What makes Manner of Motion salient? Explorations in linguistic typology, discourse, and cognition. In M. Hickmann, \& S. Robert (Eds.), Space in languages: Linguistic systems and cognitive categories (pp. 59-81). Amsterdam/Philadelphia: John Benjamins.

Talmy, L. (1985). Lexicalization patterns: Semantic structure in lexical forms. In T. Shopen (Ed.), Language typology and syntactic description, vol. 3: Grammatical categories and the lexicon. Cambridge: Cambridge University press.

Talmy, L. (1991). Path to realization: A typology of event conflation. Proceedings of the $17^{\text {th }}$ Annual Meeting of the Berkeley Linguistics Society (pp. 480-519). Berkeley, CA: Berkeley Linguistics Society.

Talmy, L. (2000). Toward a cognitive semantics, vol. 2. Cambridge, Mass.: MIT Press.

Treffers-Daller, J., Ozsoy, A. S., \& van Hout, R. (2007). (In)Complete acquisition of Turkish among Turkish German bilinguals in Germany and Turkey: an analysis of complex embeddings in narratives. International Journal of Bilingual Education and Bilingualism, 10(3), 248-276. http://dx.doi.org/10.2167/beb443.0 


\section{Notes}

Note 1. Slobin (2006: 70) has made assessments of manner salience across languages from various aspects of language use, such as ease of lexical access, imagery and understanding of manner verbs, conversational use, child language acquisition, use in elicited oral narratives, use in creative fiction, translation of creative fiction, metaphoric extensions of manner verbs, etc.

Note 2. In the present study, following Slobin (2002), the words like fall and its equivalent 掉 diao4 in Chinese are categorised as path verbs, while Chen and Guo (2008) categorise fall as a manner verb.

Note 3. Slobin (2006: 70) comes to this conclusion on the basis of assessments of manner salience across languages from various aspects of language use, such as ease of lexical access, imagery and understanding of manner verbs, conversational use, child language acquisition, use in elicited oral narratives, use in creative fiction, translation of creative fiction, metaphoric extensions of manner verbs, etc.

Note 4. 开 kail is polysemic in Chinese. When used as a motion verb, it functions both as a cause of motion verb and a path verb. It appears in the second slot in serial verb constructions indicating separation or dissemination when it is a path verb.

Note 5.追逐 zhuilzhu2 is a fixed phrasal verb treated as the equivalent of 追 zhuil meaning "pursue".

\section{Appendices}

Appendix 1. Bank story

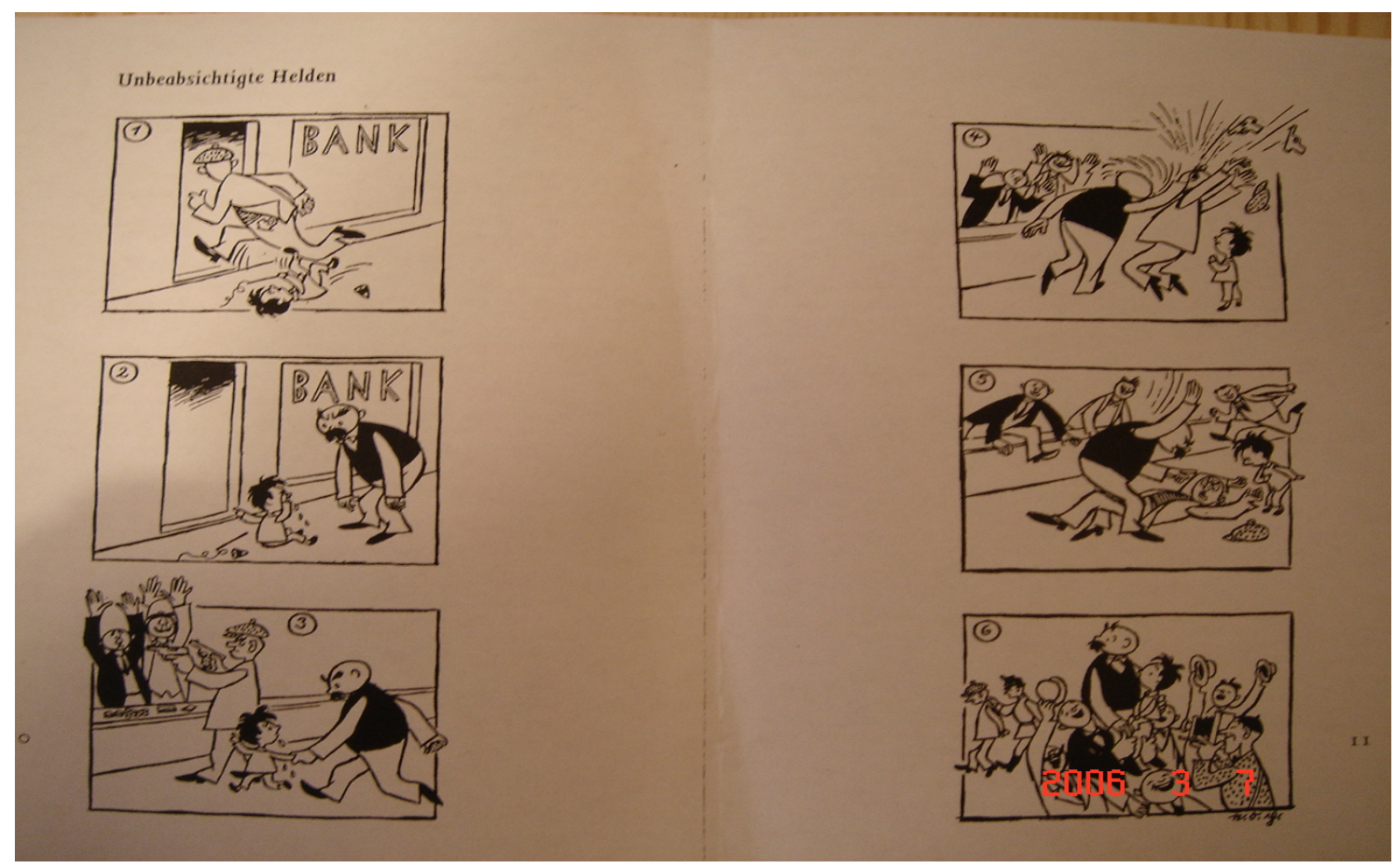




\section{Appendix 2. Dog story}

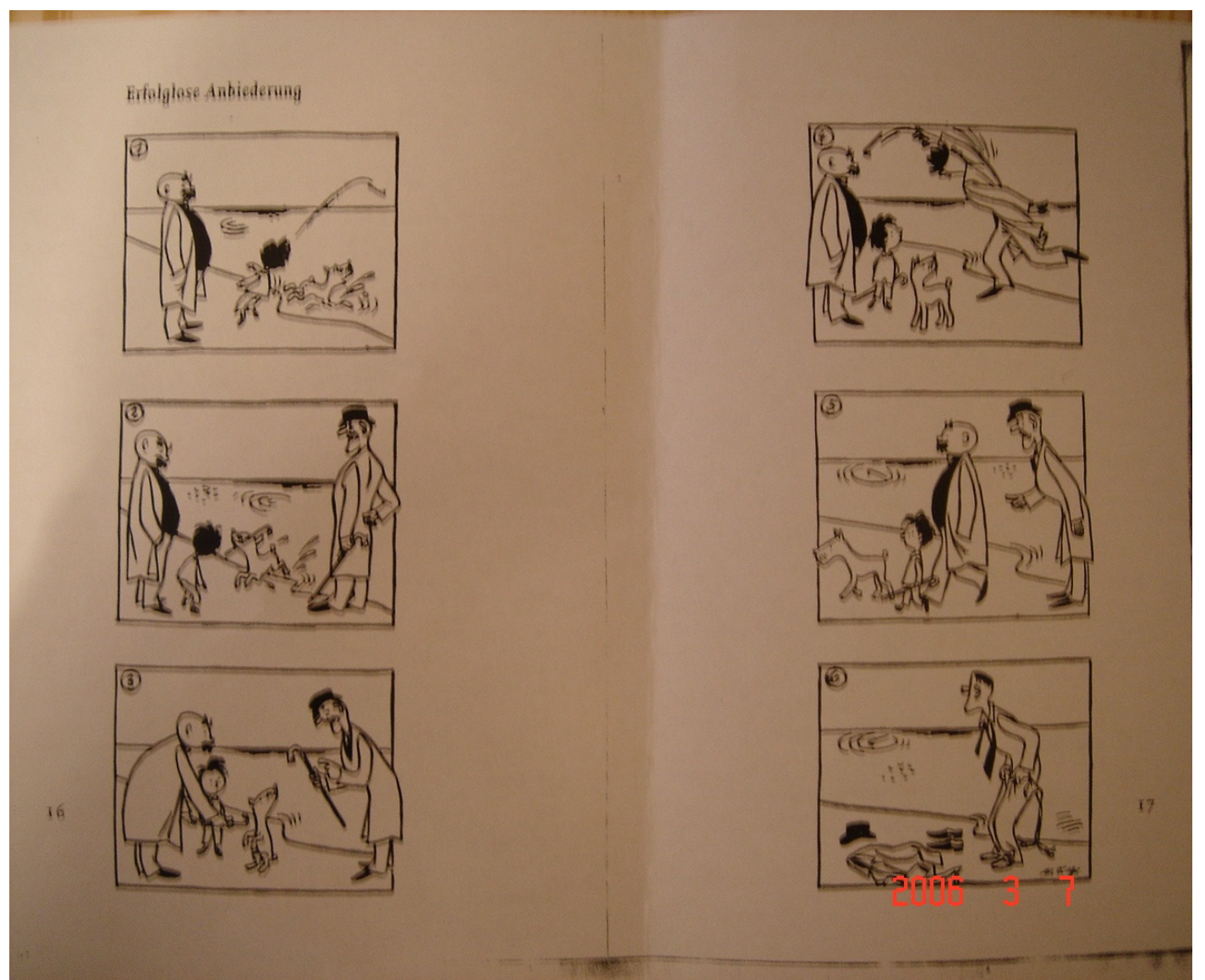

Appendix 3. Picture 2 and 3 of Frog goes to dinner

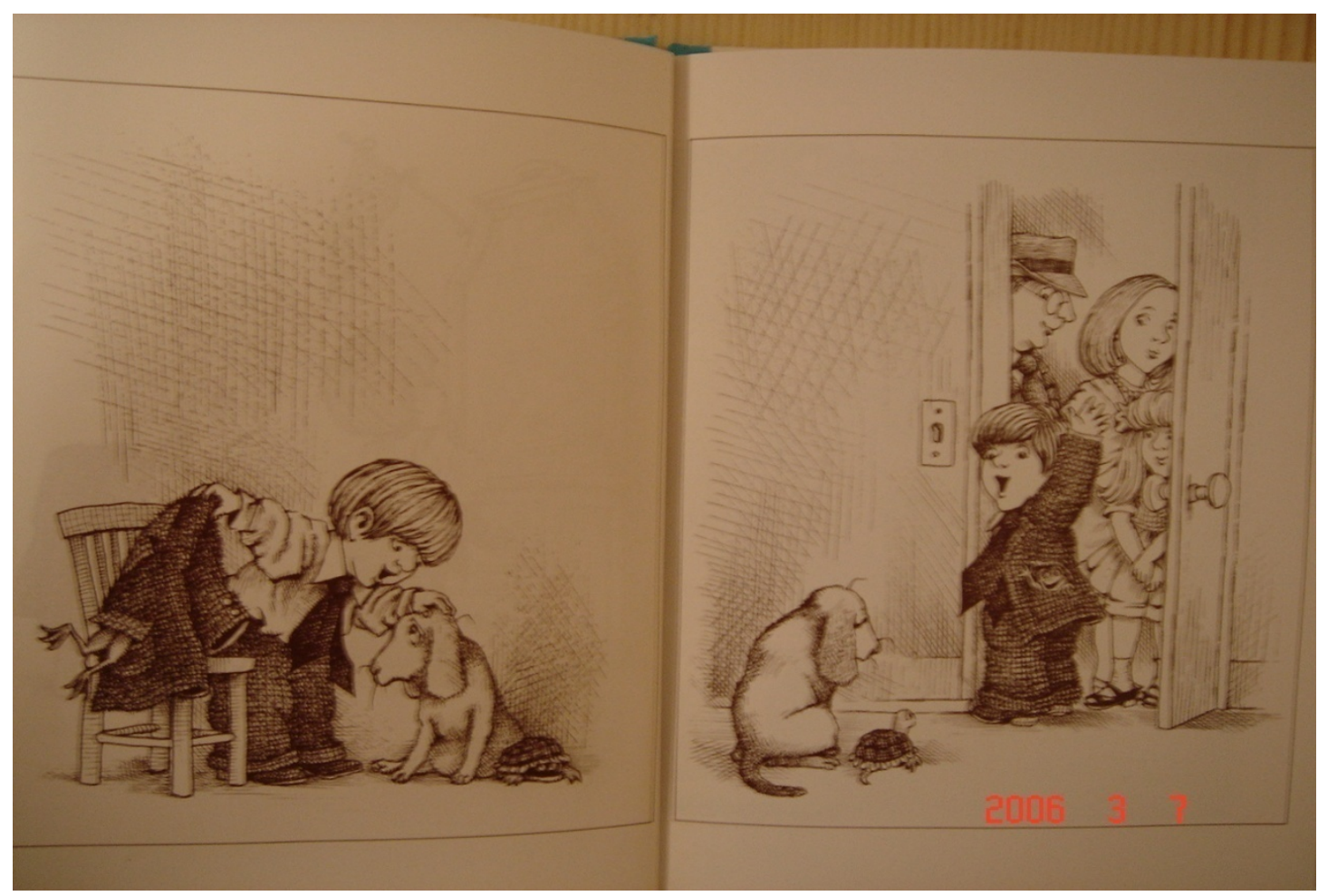


Appendix 4. Picture 2 and 3 of Frog, where are you?

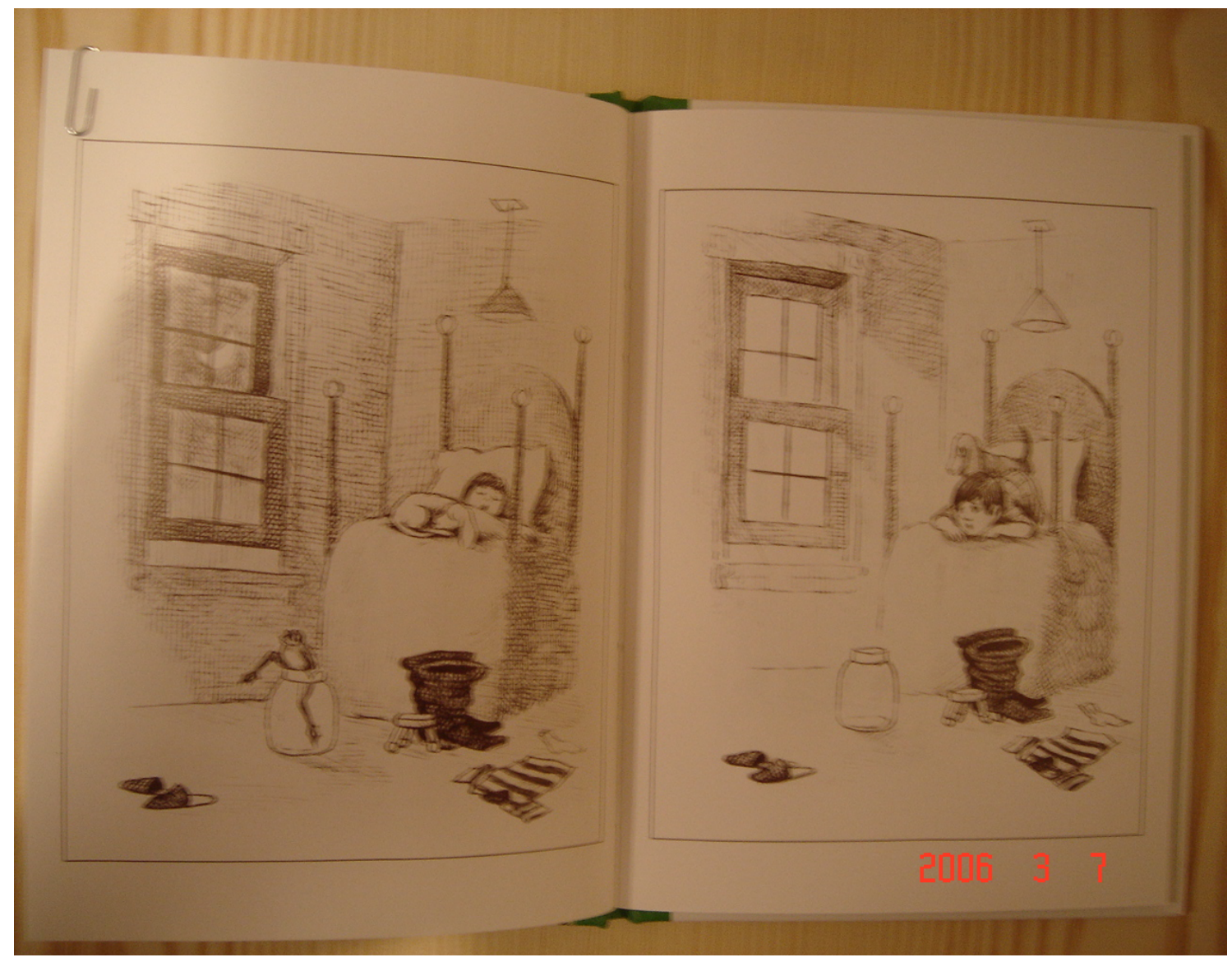

\section{Copyrights}

Copyright for this article is retained by the author(s), with first publication rights granted to the journal. This is an open-access article distributed under the terms and conditions of the Creative Commons Attribution license (http://creativecommons.org/licenses/by/3.0/). 